Western University

Scholarship@Western

Department of English Publications

English Department

Fall 10-2009

\title{
Dr. Balachandra Rajan: From India to Canada, Fragments in Search of a Narrative - In Memoriam
}

Teresa Hubel

Huron University College, Canada, tdhubel@huron.uwo.ca

Follow this and additional works at: https://ir.lib.uwo.ca/englishpub

Part of the Literature in English, Anglophone outside British Isles and North America Commons, $\underline{\text { Race, Ethnicity and Post-Colonial Studies Commons, and the South and Southeast Asian Languages }}$ and Societies Commons

Citation of this paper:

Hubel, Teresa, "Dr. Balachandra Rajan: From India to Canada, Fragments in Search of a Narrative - In Memoriam" (2009). Department of English Publications. 133.

https://ir.lib.uwo.ca/englishpub/133 


\title{
Dr. Balachandra Rajan: From India to Canada, Fragments in Search of a Narrative-In Memoriam
}

\author{
Teresa Hubel \\ Huron University College
}

$\mathrm{W}$ hile preparing to write this tribute to Dr. Balachandra Rajan, I found myself wondering what in his eminent life I should be recalling for your benefit. Which events or personal preferences, habits, gestures, or even political commitments and publications can be tallied up to create some kind of coherent narrative that conveys the gist of him? The dilemma is that, when it comes to Dr. Rajan (who in my memory can never be remembered as anyone other than Dr. Rajan, not Balachandra or Bal, as he was known by his friends here), the details I could cobble together to create the gist that he was to me are, I expect, different from what others might gather, others who have also known him, respected him, and loved him, as I did, and who, like me, found their lives changed by him. I suspect that his colleagues in Milton scholarship and in his department at the University of Western Ontario are better able to describe his public side: his many professional achievements, for instance, and all his theoretically diverse and numerous publications. It seems to me that, because I spent so much time apparently idly talking with Dr. Rajan in the last twenty years or so, mostly about his life and the people whose lives mattered to him and about India, a country that partially defined him and also often annoyed him and the fascination for which brought us together initially and then many, many times afterward, it would make sense for me to linger awhile over the decisions he made that brought him, finally, to London, Ontario, Canada. The man who impressed me was somewhere in those decisions.

In 1920 Dr. Rajan was born in Burma and into privilege, the kind of privilege that only late colonial India could produce. (Burma was then a part of Britain's Indian Empire.) His father was a member of the 
elite ranks of the Indian Civil Service at a time when Indian men were just beginning to move into its higher reaches, but, more than this, the members of both the paternal and maternal branches of his Brahmin family could count themselves among that group whose sons had a hand in ruling the country and who would take over the gorernment after the British left in 1947. In relation to the some 300 million who constituted India's population when Dr. Rajan was young, this group of families was a small but commanding minority. The Indian novelist Nayantara Sahgal describes them in her novel Rich Like Us as "the tiny wee handful whose uncles and aunts all know each another and who are in charge of everything without a notion of what 'everything' really is" (101).

The fact that Dr. Rajan was the child of influential parents isn't really the point of this story. The point is this: when you ae born to a level of privilege that virtually guarantees you a high-ranking job for life because you are the son of a well-known family with consequential connections, it is easy to move seamlessly from one extraordinary advantage to another. Dr. Rajan could have spent his whole life in India comfortably ensconced in a job in the government or business or the university that would have brought him a luxurious style of living and that would have ensured his perpetual treatment, perhaps especially in his old age, as a respected and powerful man.

This is the path that was mapped out for him by his amily, who sent him first to the Presidency College in Madras and subiequently to Cambridge so that he could start that journey toward influnce and authority. Cambridge was chosen precisely because it was (ne of those places that marked out these young men as the next gen:ration who would take over the reins of rulership from their fathers. And he enrolled in economics because that was one of the subject that paved the pathway to influence and authority. If he had made tle choice to follow the route laid out for him, and this was an obvious atd relatively trouble-free choice for him to have made, he could have livid a life that would have seen him periodically garlanded by admirers and supplicants who wanted his attention and sought his favour. Ald when he died, all his neighbors would have known about it and those admirers and supplicants and neighbors would have lauded him in in elaborate funeral that would have involved more garlands and a crowd of mourners. But Dr. Rajan was one of those people to whom lifi didn't just happen.

He took economics at Cambridge because his father nsisted that he do so; he even excelled at it, earning a first-class tripos, lecause that was expected of a son of this family. But he grabbed the frst opportunity that presented itself to take charge of his own life andsteer it into 
uncharted waters, that first opportunity being the Second World War, which made transportation between India and Britain difficult for nonmilitary purposes. Knowing that his father, who had stopped him before from pursuing this particular goal, could not stop him now because he could not reach him, Dr. Rajan switched into the field, English literature, which he had long wanted to be part of, where, before the war ended, he had managed to turn himself into a rising star in Milton studies.

It helped, of course, that he was eloquent, surpassingly bright, and determined, but having the prestigious E. M. W. Tillyard as his dissertation supervisor and C. S. Lewis as one of his examiners seemed to suggest that, within the protected and apparently stable realm of Britain's elite academy, his future was set. He strode confidently into that future in 1947, the year of India's independence, when, while still a young man in his twenties, Dr. Rajan leapt into the scholarly arena with the publication of two books, Paradise Lost and the SeventeenthCentury Reader and T. S. Eliot: A Study by Several Hands. Consider what an accomplishment these publications were: here was a young man in a world that was not his own (though a British subject, he was clearly a foreigner in England) with two books to his credit before he was thirty years old, and this at a time when many scholars would win their reputations with the publication of one book alone on which they could rest comfortably, their laurels intact for the remainder of their careers. Remember, this was the pre-"publish-or-perish" days and, perhaps more important, this was Cambridge in the 1940 s, a place that itself was resting on its own centuries-old laurels, having secured its preeminence through the combined might of the British Empire and the British class system. That he had produced two books while still barely out of his graduate school and still in his twenties must have seemed a prodigious feat.

Not quite understanding the whole Milton obsession myself, I once asked him why he chose to study this author and his magnum opus. His decision had everything to do with the historical moment in which it was made. It was the 1940 s, when nationalist Indians were about to accomplish the aim that was implicit even in the 1885 founding of the Indian National Congress: that is, they were about to chuck the British Empire out of India for good, and not all those white rulers were happy to go; in fact some of them saw nationalism as a betrayal of their love for and dedication to India, saw Indians as ungrateful and conniving for wanting to wriggle out from under British control. Given that the rewards of Empire fell so unevenly into the hands of Britain's elite men, it makes sense that these men, many of whom were Cambridgeeducated or Cambridge-based, should take this international event as a 
personal affront and should, therefore, begin to see the rising young Indian star in their midst as suspect. Dr. Rajan felt increasingly unwelcome, saw himself descending from the status of rising star to that of pariah, from worthy disciple to unappreciative rebel. And where does Milton fit into all this personal and international drama? Milton was, he once told me, regarded as a quintessentially English writer, whose erudite and intricate writing only true Englishman could properly decipher, a writer beyond the reach of colonials and the colonized. He studied Milton's epic because, he said, he wanted to show them, the Miltonists, the Cambridge authorities, those imperialists who often wore liberal clothing, that an Indian could master the writer that the Empire had claimed so exclusively as its own.

It was a choice made by a rebellious young man who was also an Indian nationalist, and in the short run it cost him. In spite of having published two acclaimed scholarly books by the time he was twentyseven, in spite of having been promised a position at Cambridge, where there was a tradition of rewarding certain well-regarded graduate students with a pleasant and protected livelihood in historically celebrated surroundings, the success of Indian nationalism brought out the petulant bully in Cambridge authorities, and he found that there was no longer a place for him there.

He was intensely disappointed and disillusioned when he returned to India, where he became an official of the Indian Foreign Service in what was surely one of the most hopeful though badly bruised of postcolonial state administrations, Jawaharlal Nehru's first government. It was the sort of position his father had wanted for him. He remained with the Foreign Service for a number of years, working as a member of India's Permanent Mission to the United Nations in Vienna and New York, and later he was asked to contribute his eloquence to such U. N. organizations as UNICEF and the International Atomic Energy Agency. And all this while he was one half of a new marriage, having met and married Chandra and having become a father to his much loved and only child, Tilottama. They travelled together to Vienna and New York, hosted dinner parties, met celebrities and movies stars. He delivered speeches; Chandra studied Sanskrit, and, although his life, this new life among diplomats and statesmen, was a good way away from Milton and Eliot and Cambridge, still, he kept writing. In 1950 another scholarly work was published, this one on American poetry, and in 1958 his first novel, The Dark Dancer, came out, followed three years later by Too Long in the West. Taken together these novels are a study in contrasts: one, the first, set during India's terrible Partition and featuring a male protagonist who returns to India reluctantly after studying in England, is full of murder, grief, and cultural alienation; the 
other is about a young Indian woman who journeys to the West and to self-rule and then back to India, learning along the way that belonging can be global in its reach. Both, I think, tap into the horror and the optimism that sat side by side in the early era of India's independence. That he gendered these narratives seems to me to be a sign of his prescience as well as of his sensitivity to the ways in which gender realizes itself in specific experiences and conditioned responses.

He could have stayed contentedly in the Indian Foreign Service and had the life I mentioned earlier. But over a decade later the service insisted on sending him to China, when relations between India and China were tense, and violence seemed inevitable. China was not a safe place for his wife and little daughter, and he refused to go, though they threatened him with dismissal. A proud man, he resigned before they could dismiss him.

And he remade his life again, becoming a professor at the University of New Delhi. He was quite a catch for the English department, as he would have been for any English department, having by this time published so much and so variously. But the style of teaching there required him to virtually shout his lectures to classes of hundreds of undergraduates. Given that Dr. Rajan normally spoke just a few decibels above a murmur and in grammatically complicated sentences, it is hardly surprising that the students in the back could not hear or understand him. Furthermore, India's official policy of non-alignment, though it produced so many good things, also precluded the possibility of adequately funding research activities in public institutions like universities: "world-class scholarship," he said, "could not be achieved with the miserable resources of the Delhi University library, attenuated by pilferage of its best books" ("Acceptance" 68). Yet in spite of this political situation (surely the pilferage had some connection to the inadequate funding), which made it difficult for him to get the texts he needed for his continuing work on Milton's writing and, by this time, on that of Eliot, Percy Shelley, and Pound, he managed to complete a book on Yeats's poetry. But he knew he could not stay in India if he wanted to maintain the international reputation he had carefully cultivated. He left in 1964.

His decision to immigrate to North America to pursue a career in academia, first at the University of Wisconsin and finally in 1966 at the University of Western Ontario, made his personal life more difficult in some ways. Immigration to a country as far away from India as Canada for Indians in the ' 60 s often meant a parting from family and friends that would last for years. And still he came here, found it agreeable, and settled. It's impossible to say whether its agreeableness matched his expectations, which might perhaps be discerned in his second novel, 
Too Long in the West, when he describes the response of its protagonist, Nalini, to her initial encounter with North America: "She did not find the new world; rather it discovered her, unlocking the qualities she had always possessed. . . . It was the difference between being herself and the compromised product of her family's pushes and pulls" (4243). He remained, throughout the rest of his life, torn between India and Canada, valuing both the tropical civilization that had shaped him and the northern country that lauded and welcomed him.

Like many other Canadian students, I am the beneficiary of his decision to stay here with us until the end. I met him a few years after his retirement, though he was far from retired in any traditional sense, being central to Western's graduate program in English because of his reputation as a renowned scholar of Milton's writing and his growing fascination with the newer political theories that had begun to theorize a period through which he himself had lived. One of the delights of learning from Dr. Rajan was that his understanding of postcolonialism went beyond the merely theoretical, for he was a superbly selfconscious product of the Empire, which this, then-new, academic movement sought to conceptualize. In fact, just as in his two novels he anticipated feminism's recognition of gender as a defining category of existence and experience, so too did he imagine a scholarship that confronted rather than fled from the ramifications of European imperialism. As far back as 1947, when he delivered three talks on India for BBC's Third Programme, all of which were reprinted in The Listener, he began to construct an argument that sought to understand the colonialist structures through which the West conceived of India, structures that prevented westerners from being able to see India "within its own civilizational discourse" and facilitated the development of an "intellectual relationship between England and India [that] paralleled the relationship between ruler and ruled" ("Acceptance" 67). He was here anticipating the advent of the more politicized reading of literary and philosophical texts and histories that postcolonial theory would make standard some forty years later.

His talent for staying one step ahead of the academic game was evident again in 1994 when he gave the Tamblyn lectures at the University of Western Ontario, which he collectively entitled "Appropriating India: Discourse and Dominance." The subject of these four lectures represented another prescient moment in his life: for him personally, this work was a return back the way he came-to India through England. Or to use his own words from his first novel The Dark Dancer, "He walked back slowly to the strength of his beginning" (308). Within postcolonial studies, these lectures explored a textual history that was at the outset absent in our field. Colonial discourse analysis 
had generally been, before 1994, focused on the last stages of empire, the late nineteenth and early twentieth centuries. Dr. Rajan was one of the few scholars some fifteen years ago who looked further back, to before the empire was a settled fact and then a crumbling institution. So many of our current truths about the workings of imperialism are culled from a conception of empire as supremely Victorian in its ideals and behaviors. But the British Empire was inconsistent and flexible, adapting itself to harmonize (sometimes badly) with whatever political song was being sung at home. Being able to track the empire through more than one of its ages requires an expertise that can combine knowledge of more than one period of English literature and history with an appreciation for the protean manifestations of imperialism. And this was exactly the kind of dexterity that Dr. Rajan had; this was something that he knew better than the rest of us, having spent five decades immersed in the English canon, convinced of its value, and living with the consequences of its imperialism in his own life. So many postcolonial scholars today might be products of the European empires-I certainly am-but few of us could claim to possess an experiential understanding of it so laboriously won.

In 1994 at the University of Western Ontario in London, Ontario, Canada, there was no more appropriate person to tell us about imperialism and English literature than Balachandra Rajan - a man who not only witnessed the fall of an empire and participated in the decolonization of a nation but who persisted in the face of academic racism and strode so comfortably through English literature, moving with such apparent effortlessness from Milton to Yeats, from Eliot to Spenser, and then, suddenly, from Elizabeth Hamilton to Sydney Owenson. I said then and I believe still that Dr. Rajan's gift to us was not his scholarship alone but his consciousness about the material effects of empire; understanding its impact in his own life, he sought to draw its implications into the light in ours. For me, this willingness to articulate the connection between the events and emotions that constituted his personal experience of the world and the larger forces that forged cultural and political structures was his legacy.

Many of us have been Dr. Rajan's students. We all know how lucky we were to have studied with him. Although a tad intimidating because of his stature in our profession, he was nevertheless eager to talk to us, though it could not have been easy, divided as we were by history, convention, and even conversational patterns. I have yet to meet anyone who possessed the English language with the formality, the sheer grammicality, of Dr. Rajan. In the halls at Western, he was famous for speaking in compellingly perfect prose. While we, his students, spit out fragments that sought desperately to express our vaguely 
perceived insights into an empire that had shaped and then silenced us, that had somewhere along our way turned us into its unwitting advocates, sentences, even paragraphs, emerged from his lips-complete with subordinate clauses-grammatically immaculate, movingly astute. It seemed that his mind, like his legs, worked in these great, long strides.

I have seen a moment in one of his classes - and this was a particularly argumentative and loquacious group, filled up with a certainty that its members would be the ones to finally see through the opacity that our forerunners had created-a moment when he rendered us respectfully speechless. He knew what we could not because, despite all our self-assurance, we did not have his decades of considering imperialism's ramifications. He was talking about India and all at once conveying intense emotional attachment and a cool critical distance honed by years of living with the consequences of decisions made under the shadow of an empire. We, too, were under its shadow but had yet to accumulate the wisdom that only its consequences could generate.

A country, a myth, a dream, "a collective fiction," (these are all Salman Rushdie's words [112]) India, though eminently deconstructible, could still occasionally remain stubbornly absolute for Dr. Rajan, a sign that his relationship to it was complicated beyond measure. $\mathrm{He}$ could and sometimes did speak of an India that seemed to be drawn from a time when there was a great deal of truth-value in the massive monoliths of nationalism, as when he makes the following statement in his last book Under Western Eyes:

An India stripped of its differences is a subscriber, not a contributor, to world understanding. An India disrespectful of the accommodative strength that has characterized its history will be assimilated rather than accommodated to principles it will be unable to revise or even resist. To set aside or to ignore rather than to reinvigorate India's past is to deny it any distinctive entry into the future. On the other hand, to demand that a modern India, often unreceptive to its past, accommodate a culture now uncertainly located, to filiations and affiliations that seem to resist each other is to set down a compounded difficulty in India's revisionary thinking about itself. It is a difficulty India must confront. In doing so, it must succeed in not confusing the space given to it by Western revisionary thinking with the space its own articulacy is able to find for itself. (210)

Only paragraphs later, however, he would end the book with the recognition of the frailty of these imaginings that sought to stretch themselves over such vastnesses and with a hint of self-consciousness about his own stake in them: "Imagined communities are most potent in exile. They are more credible, although less compelling, amid the abrasions 
of their reinstatement" (211). It is as if here the earlier Dr. Rajan who gave nationalist speeches in 1940s England, who spoke at the U. N. in the ' 50 s, and who did not question the canon, were meeting the Dr. Rajan who was the result of the consequences of those acts, beliefs, and events and who had ruminated long on them, longer than most of us, his students, had even lived. We were privileged to have witnessed the effects of his relationship to history, for it was humbling to watch him strive to achieve some wisp of harmony between these increasingly farflung eras and to have sensed the abrasions as well as the passionate filiations that they left with him.

He took risk after risk to get here, to fashion the life he wanted. When he could have so easily, so comfortably, had another life in another world, he chose a struggle. Having spoken with him regularly in the last few months of his life, I don't believe he regretted all those decisions that put him here with us in Canada and of course with his beloved daughter, Tilottama, at the end. It is our good fortune that he was the kind of man who would choose that harder path. The ideal to which he was aiming his life was surely something akin to the one that Krishnan, the protagonist of his first novel, finally finds. It is an ideal that Dr. Rajan must at some point in his life have heard in Lord Krishna's words to Arjuna on the battlefield of Kurukshetra, for he quotes them on the last page of The Dark Dancer:

He who seeks freedom

Thrusts fear aside, Thrusts aside anger And puts off desire:

Truly that man Is made free forever.

When thus he knows me

The end, the author

Of every offering

And all austerity, Lord of the worlds

And the friend of all men

O son of Kunti

Shall he not enter

The peace of my presence?

I hope he does. I hope he did.

\section{Works Cited}

Rajan, Balachandra. The Dark Dancer. Westport: Greenwood, 1970. Print.

- "Professor B. Rajan's Acceptance Speech." South Asian Review 28.4 (2007): 67-69. Print.

- Too Long in the West. London: Heinemann, 1961. Print. 
- Under Western Eyes: India from Milton to Macaulay. Durham: Duke UP, 1999. Print.

Rushdie, Salman. Midnight's Children. London: Picador, 1982. Print.

Sahgal, Nayantara. Rich Like Us. New York: New Directions, 1985. Print. 
The preceding article, "Dr. Balachandra Rajan: From India to Canada, Fragments in Search of a Narrative, In Memoriam," was uploaded with permission from the publisher.

This article was originally published in South Asian Review, Volume 30, Issue 2, in 2009. It may not be reproduced without permission. 